\title{
Debate in Lithuania on EU Expansion to East: the Case of Turkey
}

\begin{abstract}
Although Turkey has been knocking on the EU's gates for almost four decades, only the echo of that knock was being heard in Lithuania until 2004. After Lithuania joined the EU, the question of Turkish membership in the EU was by design added to the agenda of the Lithuanian government's foreign policy. High-ranking state officials rushed to assure both citizens and the world that Lithuania supports the objectives of Turkey, whereas opposition (rightist) parties expressed concern about the lack of debate on this issue in the Parliament, the government and society in general. The opinion of the society, to which the Lithuanian government had not yet appealed in any way, is not clear yet. Political analysts and journalists writing on this issue tend to demonize Turkey and practically frighten the general public. It seems that a passively negative mood is settling over ordinary citizens, which in the case of referendum can become potential "No's" to the Turkish membership in the Bloc.
\end{abstract}

\section{Introduction}

In this article the author analyzes discussions in the Lithuanian public discourse on possible Turkish entrance into the EU with the purpose to find out opinions and positions of separate groups of society. The approach to the problem is both political and public. The political approach includes speeches of top politicians and statements of some parties, MPs and members of the European Parliament on the issue of Turkey. The second one involves analytical texts and initiatives of citizens which are published in the country's mass media. The purpose of this analysis is to find out how much the government's position correlates with the public's mood and if there is an unspoken agreement and congruence of positions or whether there is still some discrepancy. Since the question of the Turkish entrance into the EU will hold relevant for at least ten coming years, the results of this analysis should be useful for further discussions.

\footnotetext{
* Dr. Egdūnas Račius is associate professor and head of the Centre for Asian and African Studies of the Institute of International Relations and Political Science of Vilnius University; associate professor (part-fine) of the Political Science Department, Lithuanian Military Academy. Address: Vokiečiu g. 10, LT-01130 Vilnius, Lithuania, tel. +370-5-2514130, e-mail egdunas.racius@cr.vu.lt
} 


\section{Turkey on the Way to Europe}

Notwithstanding the several national coup de etat and successive military juntas, Turkish political elites have been actively knocking on the doors of the European Union already for several decades. Indeed, this push expresses the logical apogee of the Kemalist ideology and its eventual fruition - the founder of the Turkish Republic Mustafa Kemal back in the third decade of the XX century delineated the landmarks of Turkish Europeasation and pursing it under coercion he hoped to change the stereotyped attitude (dominant in Europe) towards the predecessor of the Turkish Republic - the Osmanli Empire, which ever since the mid- XIX century Europeans sarcastically called "the sick man of Europe" a headache for European powers ${ }^{1}$.

After Kemal's death, Turkey went through a rather stormy stage of state development, when eventually in 1982 the military transferred power to civilians and a new constitution was adopted giving birth to a system of institutional democracy, which has been functioning with minor disruptions to this day. The government is elected in practically free elections, where women can elect and be elected, candidates are nominated by almost a dozen major political parties and the supremacy of law is respected. However, the criterion of legitimacy to participate in the country's political life - the non questionability of the cult of the state founder and the Kemalist ideology during the entire existence of the Turkish Republic has remained the same - everyone, who even lightly criticizes this almost sacred line of domestic and foreign politics, immediately feels the reaction of the system, asserted by legal and military means.

If Kemal's reforms and the politics of his successors gradually formed a new type of Turk in the greater cities, life in provinces remained traditional - the patriarchate is still dominant there, local customary (in certain places even tribal) relations ${ }^{2}$, the broadly used unpaid work of children and women and the society is still agonized in a rooted culture of violence. The concerning study about this culture of violence was made public by "Amnesty International" in mid-2004 ${ }^{3}$. Various annual indexes formed by independent international organizations on economic, civil and political freedoms, which cover from 140 to 180 countries, rank Turkey below the $80^{\text {th }}$ position. This witnesses that both democ-

\footnotetext{
${ }^{1}$ About Turkish europeasation's influence on relations with Europe/EU see Larrabee F. S., Lesser I. O., "Turkey and Europe", Turkish Foreign Policy in an Age of Uncertainty, RAND, 2003, http://www.rand.org/publications/MR/MR1612/; Morin A. "Crafting A Nation: The Mythic Construction of the New Turkish National Identity in Atatürk's Nutuk", 2004, p. 26-33, http://www.einaudi.cornell.edu/europe/initiatives/pdf/Morin Paper.pdf, 6th of September, 2005.

${ }^{2}$ On August 30, 2005, BBC published a report about the prevalence of illegal polygamy among Kurdish in the southeast Turkey, http://news.bbc.co.uk/1/hi/programmes/ this_world/4165896.stm

${ }^{3}$ Turkey: Women confronting family violence", Amnesty International, June 2, 2004, http:// web.amnesty.org/library/index/engeur440132004
} 
racy and civil society in Turkey are far away from meeting European standards (EU members, as a rule, are in the first forty positions) ${ }^{4}$.

After the adoption of series of legislative packages in 2002 and 2004 Turkey made noticeable progress towards meeting the Copenhagen political criteria opening way for the EU membership negotiations. These packages initiated the country's legal system reform (e.g. parliament disbanded National Security Courts equivalent to war tribunals), and thus recalled many restrictions on free speech and political freedom, and established civil control over the armed forces. These reforms without doubt are to the credit of the Turkish government. However, the fact that certain institutional reforms were started from above a few years ago does not mean that they set in motion the process of the reappraisal of values in Turkey's society. Nor these reforms show that the Turks accept European or even Christian values.

All these things do worry Brussels, the governments of some EU countries and their societies, about Turkey's preparedness for possible EU membership. They expect Turkey (as a state and society) to be not only in Europe, but also to become a part of Europe. Unfortunately, as Mustafa Aydin has noticed "there is clear evidence that today's Europeans still think that the Turks have not yet achieved the 'standard of civilization', that is, the Copenhagen criteria in toda$y^{\prime}$ s European Union". ${ }^{5}$ This opinion can be implicitly backed by the latest results of Eurobarometer ${ }^{6}$ showing that only 35 per cent of EU citizens support Turkey's membership in the EU, and half of the respondents oppose possible Turkish membership. On the other hand, the 10 new EU members support the idea stronger (48 per cent) than the old ones, where only 32 percent of citizens support Turkey's membership in the EU.

Discussions about possible Turkish membership in the EC/EU have lasted from the 1960's. They intensified in 1999, when Turkey was officially recognized as a candidate state and reached their apogee so far in 2004 when the EU had to decide whether and when it will open the accession negotiations with Turkey. In December of 2004, the European Council agreed that the negotiations will be opened on the October 3, 2005. Disregarding the EU citizens' opposition to Turkey's membership, Brussels and many governments of the EU member states prepared themselves and their citizens for opening the EU accession negotiations with Turkey. And only a few EU member states are stricter on the question of the EU enlargement and possibly Turkey's membership ${ }^{7}$.

${ }^{4}$ For example, "Press Freedom Index", made by "Reporters sans frontiers", among 167 countries analyzed, Turkey was ranked 114, http://www.rsf.org/article.php3?id article $=11715$; "Index of Economic Freedom 2005", made by Heritage foundation, Turkey was ranked 112 among 155 countries, http://www.heritage.org/research/features/index/countries.cfm; "Human Development Report 2004", UNDP, Turkey was ranked 88 among 177 countries, http://hdr.undp.org/reports/global/2004/pdf/hdr04_HDI.pdf

${ }^{5}$ Aydin M., "The Determinants of Turkish Foreign Policy, and Turkey's European Vocation", Review of International Affairs, vol. 3, Issue 2, Winter 2003, p. 327

${ }^{6}$ European Commission, Eurobarometer 63, http://www.europa.eu.int/comm/public_opinion/archives/eb/eb63/eb63.4_en_first.pdf, July 2005.

${ }^{7}$ For example, recent speeches of political leaders in France, Holland and Germany. Look: "EU to Present Roadmap for Turkish Entry Talks", Reuters, http://www.nytimes.com/reuters/ international/international-eu-turkey.html 28th of June, 2005; BBC, EU hears fresh doubts over Turkey, http://news.bbc.co.uk/1/hi/world/europe/4189384.stm, August 26, 2005. 


\section{Turkey's Membership in the EU and Lithuania}

\subsection{Political Level}

According to the public opinion surveys in Lithuania on Turkey's membership in the EU, Lithuanians support Turkey's membership equally to the average of the EU level-31.8 per cent ${ }^{8}$. The European Commission's Eurobarometer shows a bit stronger support ${ }^{9}$. But it seems that the Lithuanian citizens' opinion does not disturb the government. It openly but not always formally declares its support for the EU accession negotiations with Turkey and eventuall Turkey's membership. This position was taken by Lithuania and confirmed at the EU Summit in Brussels in December of 2004. Then the European Council introduced some conditions and clauses saying that the EU accession negations not necessarily should end up with Turkey's membership. Shortly after the Summit, Lithuania's government members started speculating on these (essential) conditions and clauses. This is probably done because of realizing that strong support for Turkey's membership can be harmful to the government itself when the country's citizens do not support Turkey's objectives to join the EU. Meanwhile, shelving active support would not bring any harm to Lithuania or its government.

\subsubsection{The Government}

In any case, Lithuania's president Valdas Adamkus several times expressed his positive opinion on Turkey's membership in the $\mathrm{EU}^{10}$. Once giving an interview he said:

To my mind the answer should be positive. This is my personal opinion...Participating in several discussions on this question I did not hear any clearly negative positions. [...] Only one thing should be required from all European countries - it is satisfaction of criteria established for the EU countries. This is unalterable condition. If

\footnotetext{
${ }^{8}$ Ministry of Foreign Affairs of the Republic of Lithuania, Most of Lithuanians support EU enlargement, http://www.urm.lt/index.php?228118696, July 27, 2005.

The survey ordered by the Ministry of Foreign Affairs was carried out by the Market and Opinion Research centre "Vilmorus". In the survey of news portal "Delfi" 21 per cent of respondents answered positively on the question of Turkey's membership, " 67 proc. DELFI skaitytoju nepritaria Turkijos narystei ES", on July 29, 2004, http://www.delfi.lt/news/ daily/euronews/article.php?id=7183414. Another non-representative internet survey ordered by member of the European Parliament Margarita Starkeviciute was carried out in December, 2004. 45 per cents from 900 respondents were against "opening of EU accession negotiations with Turkey". 27 per cents of respondents were for Turkey's membership with some conditions and only 18 per cents supported Turkey's full membership in EU". "Lietuviu nuomonė dèl Turkijos narystės ES išsiskyrè", Publicum, http://www.vtv.lt/content/view/ 756/55/, December 3, 2004

${ }^{9}$ European Commission, Eurobarometer 63.4 http://www.europa.eu.int/comm/public opinion/archives/eb/eb63/eb63_nat_lt.pdf

${ }^{10}$ The Chacery of President of the Republic of Lithuania. Prezidentas prieme Turkijos vicepremjera A. Giuli, http://www.president.lt/lt/news.full/5236, Sepmtember 12, 2004
} 
Turkey's reforms, system and laws satisfy the EU requirements, I think there will be no moral or other obstacles for Turkey to become a part of Europe. ${ }^{11}$

Indeed, the Lithuanian government's position on Turkey's membership in the EU has always been positive. Speeches of representatives of the Ministry of Foreign Affairs demonstrate this very well. When Turkey's Minister of Foreign Affairs visited Lithuania in September of 2004, Lithuania's Ministry of Foreign Affairs distributed a statement which in no uncertain terms said that "Lithuania supports Turkey's objectives to become a member of the EU and will support the decision to open the EU accession negotiations with Turkey, if the European Commission report on Turkey is positive and the country satisfies the main membership criteria". ${ }^{12}$

The peak of discussions about Turkey's possible membership in the EU in Lithuania was in December of 2004. At that time some politicians and political analysts critically covered the internal situation of Turkey and its relationships with neighbouring countries. Minister of Foreign Affairs of Lithuania Antanas Valionis quickly publicly reacted to these discussions indirectly asking to stop them or at last urging them to be politically correct and not to criticize Turkey. According to the minister, "in discussions concerning Turkey's membership in the European Union less highly motivated assessments should be declared reservedly, otherwise it can set off national and religious hatred"13. (sic!) Lithuanian's Ministry of Foreign Affairs distributed a statement which also said that "Minister of Foreign Affairs did not agree with the opinion saying that Turkey was "not European, but a Muslim country" and the EU accession negotiations could not be opened with such a country". ${ }^{14}$ But Valionis does not deny that Turkey belongs to another civilization. Speaking on the particularity of Turkey's EU membership negotiations in the Seimas he admitted that "in the case of Turkey, it is its size and civilization barrier". ${ }^{15}$ Besides, the minister indirectly expressed his fears that "acting against Turkey could overthrow this modern Turkish government and restore Islamic fundamentalism there"16, thus giving in to his frequently cited S. Huntington and mass media. Later, the minister expressed a similar opinion:

If we do not negotiate with Turkey, we would show that Europe is xenophobic, closing itself from impact of other cultures. In this case possibly the scenario of Samuel Huntington's "Clash of Civilizations" would become a reality. Then the reformists of Turkey would loose their positions and the positions of radicals in Islamic

\footnotetext{
11 "V. Adamkus: referendumas dèl Konstitucijos Europai nereikalingas", Bernardinai.lt, http:/ /www.bernardinai.lt/index.php?-23724286, September 24, 2005

12 "Lietuva remia Turkijos sieki tapti Europos Sajungos nare", Omni.lt, http://www.omni.lt/ index.php?base/z_199046, September 12, 2004. Lithuania's prime minister Algirdas Brazauskas told the same after his meeting.

${ }^{13}$ BNS, A.Valionis: Turkija negali būti atstumta dèl religiniu ir tautiniu argumentu, http://www.delfi.lt $/$ archive $/$ article.php? $i d=5763970 \&$ categoryID $=2045412 \&$ ndate $=1104872185$, January 4 , 2005

${ }^{14}$ Ibidem

${ }^{15}$ The Seimas of the Republic of Lithuania, Twelfth (12) sessions, http://www3.lrs.lt/cgi-bin/ preps 2 ?Condition $1=246859 \&$ Condition $2=$, December 9, 2004

${ }^{16}$ Ibidem.
} 
world would be strengthened. We would start building fences that in today's globalized world are not effective and September 11, 2001 has already proved that.

Though the minister's fears that in a laïcist Turkey for so many years influenced by secularization Islamic fundamentalism which, by the way, was not present even in the Osmanli times, could "return" or misgivings that "the reformists of Turkey would loose their positions and the positions of radicals in the Islamic world would be strengthened", following the reislamization process there, are quite reasoned, relating this to Turkey's possible non-inclusion into the EU and to S. Huntington's predictions shows the superficiality of Lithuania's political rhetoric.

Answering the questions of a journalist in January of 2005, Valionis once again repeated that "Lithuania supports the European Commission's recommendations for opening the negotiations". He added that "this process will be long because Turkey's level of preparedness for the membership will be evaluated according the same criteria. For Lithuania and other countries it is important that this big and important member of NATO would follow common European values."17 A bit earlier answering the questions of MPs about Lithuania's politics in the context of possible Turkey's membership in the EU, the minister described the distribution of the EU countries' positions on this question in the following way:

Today there are three or four groups of states having different positions on Turkey's negotiations with the EU. Let's say, that the first group agrees with the European Commission recommendations to open the EU accession negotiations with Turkey and thinks that after the negotiations Turkey will become a full member of the European Union. This position is supported by Great Britain, Italy, Greece, Poland, Belgium, Netherlands, Luxembourg, Portugal, Finland, Spain, Sweden, Estonia, and Latvia. The second group - the governments agree with the European Commission recommendations and thinks that Turkey should become a member of the EU but the opposition and most of citizens oppose this position. These would be France and Germany. The other group agrees with the opening of negotiations but does not think that they should necessarily end with Turkey's membership in the EU. These would be the Czech Republic, Denmark, Hungary and Lithuania. The last group which opposes Turkey's membership in the EU and is in favour of the third road, that is, as I already mentioned, stronger strategic partnership. This position is supported by Austria and Cyprus. Ireland, Malta, Slovakia and Slovenia haven't et expressed their position. ${ }^{18}$

A.Valionis placed Lithuania into the third but not the forth group (the one that is in favour of a special partnership) referring to Huntington's "Clash of Civilizations" and fair politics - purportedly, Lithuania should give Turkey a chance and if Turkey does not blow it, it will become a member of the EU.

As one of the reasons for Lithuania's support for Turkey one can pinpoint Director of EU Sector Policies Coordination Division Vidmantas Purlys' opi-

${ }_{17}$ A. Valionis: "Rytuose mes turime labai dideli veiklos laukq", Omni.lt, http://www.omni.lt/ index.php?base/z 242208, January 6, 2005.

${ }^{18}$ The Seimas of the Republic of Lithuania, Twelfth (12) sessions, http://www3.lrs.lt/cgi-bin/ preps2?Condition1=246859\&Condition2=, December 9, 2004. 
nion that "Lithuania supports Turkey's integration objectives" because Turkey "has supported Lithuania's efforts to become a member of NATO and now we should show our solidarity". ${ }^{19}$ Turkey has occasionally reminded Lithuania of its support for Lithuania on its way to membership in NATO ${ }^{20}$.

\subsubsection{Opposition}

But the Government's policy for some MPs (especially in opposition) raises some doubts about Turkey's possible membership in the EU. The elder of the Homeland Union Group in the Seimas and the chairman of the Homeland Union Andrius Kubilius in the beginning of December of 2004 distributed a statement where he:

expressed his regrets that today the Deputy Chairmen of the Seimas were reluctant to accept inquiry and place the Homeland Union's raised question about Lithuania's position on Turkey's membership in the EU on the agenda of the Seimas session. The discussion of this inquiry at a plenary session of the Seimas would draw society's attention to this important question, allow hearing the arguments of various fractions and would lead the government to formulate an official position on this question. However, as a member of the Homeland Union Jurgis Razma who participated in the Deputy Chairmen of the Seimas meeting admitted, representatives of the ruling fractions showed no interest in public discussion on the question, they were explaining that the minister A.Valionis possibly would not be able to participate in the session and they finally agreed that the Deputy Chairmen of the Seimas would consider the question on Thursday. ${ }^{21}$

Shortly after that on December 9, 2004, minister A.Valionis had to answer quite tough questions coming from the MPs. Some of them openly accused the Government and the Ministry of Foreign Affairs of going beyond its competence and without broader discussions in the society and the Seimas or their authorization of acting in favour of Turkey. A conservative Rimantas Jonas Dagys rhetorically asked whether the minister did not think that "there should be a deeper discussion and not so hurried support for all positions which tie the greater countries" and accused the Government of hurrying in a perfunctory manner as well as irresponsibility 22 . The minister rejected all the blames and accusations from the opposition saying that this question lies within the competence of the Government and there is no necessity to consider it at length in the Seimas:

\footnotetext{
${ }^{19}$ Pakalkaitè V. Besikaupiantys debesys Vilniuje išvaike piketuotojus prieš Turkijos narystź ES, ELTA, http://www.delfi.lt/archive/print.php?id=7168896, July 27, 2004.

${ }^{20}$ While the visit of the chairman of the Seimas in Turkey in the spring of 2004 the chairman of Turkey's parliament said that he believed in "Lithuania's support for Turkey's objectives to join this honourable international organization as Turkey supported Lithuania seeking to join NATO. ELTA, Narystès ES siekianti Turkija tikisi Lietuvos paramos, http://www.omni.lt/index.php?base/z_152921, March 3, 2004

${ }^{21}$ Press agency of the Homeland Union report, http://www.tsajunga.lt/index.php?698168312, December 7, 2004

${ }^{22}$ The Seimas of the Republic of Lithuania, Twelfth (12) sessions, http://www3.lrs.lt/cgi-bin/ preps2?Condition $1=246859 \&$ Condition $2=$, December 9, 2004
} 
Do not usurp in the Parliament that what can be done in the Government. Questions related to amendments of laws and the Constitution must have the mandate from the Seimas; that's why the Ministry of Foreign Affairs, the Government, applied to the Seimas for such a mandate. But forgive us, when the mandate is not necessary. We will work on our own and bring all the detailed information about our work to the Seimas in case it asks us. Do not think that the Government and the Ministry of Foreign Affairs will start sharing with others the works that belong to its competence. ${ }^{23}$

However, members of the ruling parties in the Seimas have no united position on the question of Turkey's EU accession negotiations. According to a member of the ruling Social Democrat party LSDP and vice chairman of the Seimas Česlovas Juršènas, Lithuania owes Turkey because of its moral support for Lithuania seeking membership in the NATO. ${ }^{24} \mathrm{He}$ said that "there should be free space for Turkey because the idea of the EU enlargement [...] is to make that united welfare and democratic Europe larger. [...] I think we should feel joy and it principle is a good thing that there will be more democratic countries and the high values of the EU will be spread to all margins and in this case to the Near East" ${ }^{25}$ In his contemplations, Juršènas does not even try to place Turkey into Europe emphasizing the spread of imaginary "high values of the EU" to the Near East. Other MPs indirectly support the image of Turkey as a non European country. A member of the ruling coalition Vaclovas Stankèvičius states that Turkey is "an Islamic country belonging to an absolutely different culture. Europeans do not perceive Turkey as a part of Europe even geographically."26

Opposing to Juršènas, another member of his party, a member of European Parliament Aloyzas Sakalas is strongly against possible Turkey's membership arguing that Turkey does not belong to Europe:

The main argument why Turkey can not become a member of the EU is a legal one. The Constitutional Treaty for Europe signed by the leaders of EU member states says that "The Union shall be open to all European States..." (Articles I-1 and I-58), Turkey does not belong to Europe and the Treaty does not mention that countries of other continents or Eurasia (Turkey, Russia) could be potential EU members. There it is written that "The Union shall develop a special relationship with neighbouring countries" (Article I-57). So, according to the Constitutional Treaty for Europe, Turkey cannot be a member of the EU, but it still can be a good neighbour developing a special relationship with the EU.27

Sakalas and some other of his political colleagues (especially from the oppositional parties) have indirectly accused the Government of Lithuania and

${ }^{23}$ Ibidem.

${ }^{24}$ ELTA, Č. Juršènas: Turkija turi atitikti keliamus reikalavimus, http://www.delfi.lt/archive/ article.php?id $=7167985 \&$ categoryID $=2045412 \&$ ndate $=1122459541$, July 25, 2005

${ }^{25}$ Ibidem.

${ }^{26}$ Danilavičius V. "Pingantis euras Lietuvai nepakenks", Londono žinios, http://www.londonozinios.com/index.php?nc=naujiena\&id=150\&mnc=naujienos, June 15, 2005

${ }_{27}$ Sakalas A. "Pasakèlès Turkijai", Veidas, http://www.veidas.lt/lt/leidinys.nrfull/ 41c2af597a373, No. 51, December 16, 2004. Practically the same was said in report published by his bureau in Vilnius on the 16th of December, 2004, http://www.asdf.lt/article.php?id art=5271, January 11, 2005 
the Ministry of Foreign Affairs in particular of on the one hand having no independent political will and on the other hand hiding it from society ${ }^{28}$. These accusations very likely displeased minister Valionis whose warnings about "less highly motivated assessments" could be partly addressed to Sakalas. But later Sakalas denied "that he is against Turkey's membership because it is a Muslim country". In his point of view the main obstacle for Turkey to become a member of the EU is its geographical position. "The Constitutional Treaty for Europe says that only European countries can be members of EU. Turkey is not a European country, it belongs to Eurasia." ${ }^{29}$

A colleague of Sakalas in the European Parliament, the liberal centrist Eugenijus Gentvilas, despite supporting the opening of negotiations with Turkey also criticized actions of the Lithuanian government and the the Ministry of Foreign Affairs concerning this question: "I can openly say that Europe for several months is simply boiling with discussions about opening the EU accession negotiations with Turkey. But in Lithuania it is calm. There were a few remarks that Lithuania supports the opening of negotiations and that's all. No opinion polls, no analytic articles... and no emotions in the society. Besides, it was the same with very hurried ratification of the Constitutional Treaty for Europe." ${ }^{\prime 30}$ He was also angry with the Minister of Foreign Affairs A.Valionis: "I do not think that Lithuania without doubts has to support Turkey's membership because of what Valionis has squeaked." ${ }^{\prime 31}$ Gentvilas also thinks that Turkey is not a European country. According to him, "Turkey's culture is based on the Asiatic tradition with a strong impact from Europe." ${ }^{\prime 32}$ Besides, he warned that if Turkey becomes a member of the EU, "Lithuania's contributions to the EU budget will grow by 100 million Litas annually and the EU payments from structural funds will decline." ${ }^{\prime 33}$ Nevertheless, similarly to A.Valionis, E.Gentvilas frightens that in the case Turkey will not be a member of the EU, "Islamic fundamentalists" will return to power:

Different Turkish governments in this modernizing country worked step by step constantly fighting against savagely resisting Islamic fundamentalists. If the EU does not open negotiations, this element will rise up and will wipe out today's government which hasn't yet attained its objectives. Europe in that case will have an Iranian or Iraqi type monster where all economic reforms will be stopped and the human and national minorities' rights will be finally forgotten." ${ }^{\prime 34}$

So, according to Gentvilas, Turkey is between "two civilizations and worldviews. Certainly, Europe has not and cannot lead Turks to Christianity and to

\footnotetext{
${ }^{28}$ Ibidem.

${ }^{29}$ BNS, A. Valionis: Turkija negali būti atstumta dèl religiniu ir tautiniu argumentu, http:/ / www.delfi.lt $/$ archive $/$ article.php?id $=5763970 \&$ categoryID $=2045412 \&$ ndate $=1104872185$, January 4, 2005.

${ }^{30}$ Gentvilas E. "Rimbas ir saldainis Turkijai", Omni.lt, http://www.omni.lt/index.php?ba-

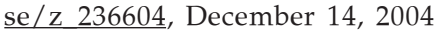

31 "Europarlamentarai sprendimus už Lietuvą priima patys", Voruta, No. 20 (566), November 12,

2004, http: / / www.voruta.lt $/$ article.php?article $=654$

${ }^{32}$ Gentvilas (note 30$)$

${ }^{33}$ Ibidem.

${ }^{34}$ Ibidem.
} 
demand from them to give up their traditions. But it would be silly to leave Turkey to its fate and make it a bastion of Islam or even terror".

So far the most active in this political discussion has been the Homeland Union. Though its previous leader, the Honorary Chairman of the party and a member of the European Parliament, Vytautas Landsbergis supports Turkey's bid $^{35}$, other members of the party are not so favourable. Deputy elder of the parliamentary Homeland Union Group in the Seimas Jurgis Razma signed a petition of an international public movement "Voice for Europe" which urged to never open negotiations with Turkey or accept this country into the EU. Then, he explained that "special partnership is better than imitation of negotiations. Having a special treaty would allow Turkey to feel comfortable and integrate into European processes without trying to mix different cultures and traditions". ${ }^{36}$

Another conservative and a member of the European Parliament Laima Andrikienè said that "she understands Lithuanian and other EU countries' citizens who are against opening the EU accession negotiations. According to her, the EU enlargement also has its own limits and there are more arguments against Turkey's membership in the EU than in favour of it. 'Today we have to think not only about the start but also about the end of the negotiations, its outcomes for both the EU and Lithuania. That's why I understand these citizens of Lithuania and other EU member states who are against the opening of negotiations with Turkey that according to the agreement of the previous year will start very soon - on October 3.'" She admitted that "after detailed analysis of the whole big European Parliament report on Turkey she spoke and voted against opening accession negotiations with Turkey" ${ }^{37}$ Andrikiene subscribed to the opinion of many European politicians that Turkey should be satisfied having a privileged partner status. ${ }^{38}$

From Lithuanian politicians' speeches and discussions one can draw a conclusion that many of them are not so generous to Turkey despite a positive Governmental position on the question of opening the negotiations. Politicians opposing Turkey's membership in the EU generally present the same standard packet of "Turkey's problems" involving aspects of its domestic and external politics. Although most of them agree that some of the problems with or without the help of EU could be solved in ten or more years time (until the hypothetical end of the EU accession negotiations with Turkey in 2015), other "problems" identified as permanent constantans (geography, religion, demography) will never allow Turkey to become a European country and at the same time to become a full-fledged member of the EU.

The rigidity and awkwardness of the Lithuanian Government and the the Ministry of Foreign Affairs in considering the question of possible Turkey's

${ }^{35}$ ELTA, $V$. Landsbergis ragina balsuoti už derybu dèl Turkijos narystès ES pradžia, http://www.bernardinai.lt/index.php?263796998, December 9, 2004

${ }^{36}$ Pakalkaitė V. Besikaupiantys debesys Vilniuje išvaike piketuotojus prieš Turkijos narystź ES, ELTA, http://www.delfi.lt/archive/print.php?id=7168896, July 27, 2005

${ }^{37}$ Ibidem. In Laima Andrikiene's personal portal www.laimaandrikiene.lt a survey on the question of Turkey's EU membership was carried. Most of its respondents answered the question negatively.

${ }^{38}$ Europos informacijos centras, L. Andrikiené siūlo strateginès ES-Turkijos partnerystès keliq, http://eic.euro.lt/index.php?-66031732, December 14, 2004 
membership both at home in Lithuania and on the broader EU level has split Lithuania's politicians. On one side are the highest officials of Lithuania (leaders of the leading parties, Prime Minister, Chairman of the Seimas, Minister of Foreign Affairs and the non-partisan President) and those politicians who silently support them, while within the other one could make out several "groups". One of these "groups" is the Homeland Union which insists on open discussions on the question and not necessarily opposes the negotiations with Turkey. The other oppositional parties (especially marginal and with no representation in the Parliament) and politicians from the ruling parties who have negative individual position on the question belong to the second "group". To the third "group" belong some members of the European Parliament opposing negotiations with Turkey. The first and the third "groups" were the most active opponents of the Ministry of Foreign Affairs and this discussion among them took at time an imperative (from the side of Ministry), sharp and even personalised (from the side of Euro-parliamentarians) tone. The third "group" is exceptional because it influences decisions not only in Lithuania but also in Brussels and Strasbourg. That is why one can speak about a double-sided Lithuanian position on the question of the EU accession negotiations with Turkey - on the one hand, Lithuania's government supports the opening of negotiations, yet on the other, some members of the European Parliament (supposedly half of them) vote against the negotiations with Turkey during the sessions of the European Parliament. Besides, the Euro-parliamentarians were the only ones who tried to find out the moods of Lithuanian citizens and argued that they voted taking into account these moods.

\subsection{Public Level}

\subsubsection{Mass Media}

Probably one of the first to call onto Lithuanians for discussion on the question of Turkey's possible membership in the EU was Egidijus Vareikis. In the spring of 2004 in his considerations on the question he presented a few "pros" and "contras". ${ }^{39}$ Among the "contras" was the one that "despite Turke$y^{\prime}$ s declarations of its secularity, it is an Islamic country and it will never naturalize in such a Western Christian construct as the EU is. No matter whether Christianity will be mentioned in the Constitution for Europe, Turkey's membership would apparently destroy the understanding of the so called European identity". However, even back then Vareikis supported the opening of negotiations with Turkey. Later, once he returned to the Seimas and became a member of the Parliamentary Group for the Relations with Turkey, Vareikis basically repeated his positive position on Turkey's membership. ${ }^{40}$

\footnotetext{
${ }^{39}$ Vareikis E. Ar Turkija turètu tapti Europos Sajungos nare?, Bernardinai.lt, March 1, 2004 http:/ /www.bernardinai.lt/index.php?-2030592092

${ }^{40}$ Vareikis E. "Turkija Europoje visada bus kitokia", Europos komitetas, http://www.euro.lt/izinios/2003 01 kitokia.php
} 
Unfortunately, after Vareikis' call for discussion there was no reaction in the Lithuanian mass media for more than half a year. Only in the end of 2004 half a dozen of articles about Turkey's possible membership in the EU were published. One of the observers, Mantas Martišius, drew readers' attention saying that "Turkey's membership would be apparent argument against Samuel Huntington's myth about the clash of Christian and Islamic civilizations and would prove that the confessants of these religions can live together." ${ }^{11}$ But he also found a lot obstacles related to Turkey's foreign policy (especially with neighbouring countries) that would not allow the country for a long time or even for ages to satisfy the membership criteria. A weekly "Horizons of the $21^{\text {st }}$ century" published a bit scarring short article on the topic. ${ }^{42}$ Česlovas Iškauskas, another political analyst, also published similar considerations at the time. ${ }^{43}$

Later, articles in the Lithuanian mass media on the same issue reappeared in the summer of 2005. Though they were provoked by the referendums in Holland and France as well as terrorist attacks in London, the observers did not present any new original ideas. Juozas Ruzgys warned that "Turkey would bring with itself that culture and belief which are not compatible with Christian roots." ${ }^{44}$ Valentinas Mité, who lives in the Czech Republic, where he works for the Radio Free Europe, wrote in his article that Turkey "in every way is different from the EU members" and "the question of Turkey's membership is a problem of different cultures and religions and also historical traditions". According to Mite, "the history of European and Turkish relationships gives little optimism. Europe and the Ottoman Empire fought against each other several times. The associations of a Turk being a brutal invader are in the minds of many Europeans and many Turks still remember the Crusades." ${ }^{\prime 45}$ An observer with the weekly "Atgimimas" Deividas Šlekys in his article "The Dilemma of Brussels"46 wrote that the opening of the negotiations with Turkey signifies a new stage in the EU enlargement, which "it seems will be done at the expense of another big neighbour of the EU. This neighbour is the Ukraine". This remark of Šlekys reminds us of the fears of some Lithuanian politicians that the Ukraine, which is more relevant to Lithuania, will stay overboard of the EU. Some of them (e.g. Rimantas Dagys) in the meeting with minister Valionis and on other occasions suggested for the Lithuanian government to have a more principled position

\footnotetext{
${ }^{41}$ Martišius M. Išorines kliūtys Turkijos kelyje i ES, Bernardinai.lt, December 29, 2004 , http:// www.bernardinai.lt/index.php?-417649794

${ }^{42}$ Katinas P. "Musulmonai ateina!", XXI amžiaus Horizontai, http://www.xxiamzius.lt/archyvas/priedai/horizontai/20041222/1-1.html

${ }^{43}$ Iškauskas Č. "Ar Turkija verta būti ES nare?", Penki kontinentai online, 16th of December, 2004 - 1st of January, 2005 ., http://online.5ci.lt/Article.asp?Lang=L\&ArticleID=7352, January 11, 2005

${ }^{44}$ Ruzgys J. "Europos islamizacija", Leono XIII fondas, 28th of April 2005, http://www.leonoxiiifondas.lt/index.php?id=146, September 6, 2005.

${ }^{45}$ Mitè V. Turkijos narystè kabo ant plauko, Bernardinai.lt, http://www.bernardinai.lt/index.php?1277576973, September 10, 2005.

46 Šlekys D. "Briuselio dilema", Atgimimas, http://www.atgimimas.lt/ ssi.php?id=1104153220\&current=2, December 27, 2004.
} 
and to raise in Brussels and elsewhere the question of the Ukrainian membership in the EU. Valionis, in answering these urges, said that the Lithuanian government fully supports the Ukraine's Euroatlantic membership objectives. He added that the Ukraine will have to work hard if it wants to satisfy the EU membership requirements and to join the $\mathrm{EU} .{ }^{47}$

\subsubsection{Civic Initiatives}

Probably one of the strongest initiatives calling Lithuanians to discuss the question of Turkey's membership was a picket near the Seimas in July of 2005. Actually, this action was organized by non-Lithuanians. It was organized by the movement "Voice for Europe." ${ }^{48}$ A Lithuanian Vilius Ališauskas who presented himself as the coordinator of the movement in Lithuania explained that the motto of the picket was: "Yes for Turkey, No for Turkey's membership in the EU". ${ }^{49}$ Alas, the participants of the action failed to draw the interest of inhabitants of Vilnius on the question - only a handful of MPs and several passersby joined the picket. The organizers admitted that it was a wrong time for such a picket because "most members of Lithuanian nongovernmental organizations were on vacation".

Mass media spotted this picket, but it had not evaluated it very seriously. A reporter with the news agency ELTA Vija Pakalkaite for example rallied in her article that participants of the picket were late to show up and dispersed after less then four hours scared by the gathering clouds. ${ }^{50}$ Mite around the same time while observing Turkey membership perspectives doubted that "recently in Lithuania established opponents of Turkey membership could change anything" and added that "similar organizations in France and Germany can change a lot". ${ }^{51}$ However, the organizers and their "spokesman" Ališauskas doubtlessly expressed the opinion of a big part of Lithuanians. According to Ališauskas, "Turkey is not democratic, has lots of problems with its neighbouring countries and ethnic minorities, does not propagate human freedoms and political rights, does not cherish European culture and values and geographically is out of Europe" ${ }^{\prime 52}$

\footnotetext{
${ }^{47}$ The Seimas of the Republic of Lithuania, Twelfth (12) sessions, http://www3.lrs.lt/cgi-bin/ preps 2 ?Condition $1=246859 \&$ Condition $2=$, December 9, 2004

${ }_{48}$ Official site of the movement: http://www.voiceforeurope.org/, 2nd of September, 2005

${ }^{49}$ Pakalkaitė V. (note 36). Arguments against Turkey's membership in EU are enumerated in the article "The Republic of Turkey is not ready for accession talks with the EU. The European Union is not ready for accession talks with Turkey" in the official site of "Voice of Europe". http: / / www.voiceforeurope.org/index.php?option=com_content\&task=view\&id=13\&Itemid=17\&lang=LTU, September 6, 2005

${ }^{50}$ Pakalkaitė V. Besikaupiantys debesys Vilniuje išvaike piketuotojus prieš Turkijos narystę ES, ELTA, http://www.delfi.lt/archive/print.php?id=7168896, July 27, 2005

${ }^{51}$ Mitè V. (note 45)

${ }_{52}$ BNS, Lietuviai jungiasi prie tarptautinés iniciatyvos tarti griežta "ne" Turkijos narystei ES, http:/ Lwww.bernardinai.lt/index.php?-1807643198, July 26, 2005
} 
After reviewing the Lithuanian mass media of the last two years one sees a clear trend of demonizing Turkey in the Lithuanian mass media. Practically all articles of Lithuanian observers are warning and scarring or even openly antagonistic to Turkey. Hence it is hard to evaluate what impact on the public opinion these articles have but one can guess that because of having no alternative (positive toward Turkey) position many Lithuanian citizens go along with the insistent emphasizing of negative facts and processes in Turkey and hold and strengthen stereotyped negative view on this EU candidate country.

\section{Conclusions}

In summary, two conclusions could be drawn:

- The Lithuanian Government (in the person of the Ministry of Foreign Affairs) and the whole political level of Lithuania are inert. This inertness is more conditioned by the government's spinelessness than its integrity or political insight. It also covers the majority of the Seimas which practically does not control the government. There are reflexive voices in the opposition of the Seimas that have been calling for broader discussions in the Seimas in particular and Lithuanian society in general. But it is too weak and split in order to make their suggestions audible for the ruling majority. The only group of Lithuanians who actively discuss Turkey's possible membership are the members of the European Parliament. But their opinion not only disagrees with the official government's position but mostly is hostile toward it. That is why one can argue that there is a double-sided position on the political level - a positive government's (ruling majority's) position which is not widely supported in society and a cautious and negative position of most Lithuanian members of the European Parliament supported by the majority of Lithuanians.

- One can also speak about apathy on the societal level - the question of Turkey's EU membership for most citizens of Lithuania is not relevant. Their activity is not stimulated either by mass media or civil movements or nongovernmental organizations - practically everyone notices more obstacles for Turkey to become an EU member see more harn than the advantages or benefits to the EU, Lithuania and Turkey itself if et join the EU. Such a position of observers corresponds to the negative opinion of the majority of Lithuanians on the question of Turkey's membership. Besides, the mass media further demonizes and stereotypes Turkey forbidding the society to weight and rethink its positions. Therefore, it is likely that the majority of Lithuanians would vote against Turkey's membership in the EU if such a referendum is held (minister Valionis has publicly mentioned about such a possibility). However, it is more likely that the Government will not allow such a thing and will make all relevant decisions itself. 